\title{
Performance of sheep fed forage cactus with total water restriction
}

\section{Desempenho de ovinos alimentados com palma forrageira com restrição total de água}

\author{
CORDOVA-TORRES, Alma Violeta ${ }^{1}$; COSTA, Roberto Germano ${ }^{2 *}$; MEDEIROS, \\ Ariosvaldo Nunes de ${ }^{2}$; ARAÚJO FILHO, José Teodorico ${ }^{3}$; RAMOS, Alenice Ozino ${ }^{4}$; \\ ALVES, Neymar de Lima $^{3}$
}

\author{
${ }^{1}$ Universidade Federal da Paraíba, Centro de Ciências Agrárias, Areia, Paraíba, Brasil. CNPq-TWAS. \\ ${ }^{2}$ Universidade Federal da Paraíba, Centro de Ciências Agrárias, Departamento de Zootecnia, Areia, \\ Paraíba, Brasil. \\ ${ }^{3}$ Universidade Federal de Alagoas, Centro de Ciências Agrárias, Departamento de Zootecnia, Rio Largo, \\ Alagoas, Brasil. \\ ${ }^{4}$ Universidade Federal da Paraíba, Centro de Ciências Agrárias, Areia, Paraíba, Brasil. CAPES. \\ *Endereço para correspondência: betogermano@hotmail.com
}

\section{SUMMARY}

A lack of water in livestock production can limit the performance of the animals; therefore, the objective of this study was to evaluate the effect of water restriction on the growth performance of sheep that were fed forage cactus (Nopalea cochenillifera). Forty-two male sheep were used, with an average age and weight of \pm 100 days and $18.75 \pm(2,05) \mathrm{kg}$, respectively, and they were fed diets containing concentrate, mineral mixture and three levels of substitution (30, 50 and $70 \%$ ) of Tifton hay with forage cactus (Nopalea cochenillifera). The animals were slaughtered when they reached $32 \mathrm{~kg}( \pm 1 \mathrm{~kg})$ of body weight or 90 days. The experimental design was a $3 \times 2$ factorial arrangement, forage cactus $(30,50,70 \%)$ $\mathrm{x}$ water (with or without water) plus a control group $(\mathrm{n}=6)$. Variables were analyzed using Tukey and Dunnett's test at 5\% with PROC GLM in SAS software. Voluntary water intake and dry matter intake (DMI) decreased with the inclusion of forage cactus; however, preformed water intake and total water intake increased with the inclusion of forage cactus. Water restriction and its interaction with the treatments had no effect on animal performance. Daily weight gain was higher for the diets with 30 and 50\% forage cactus inclusion, at 174 and $155 \mathrm{~g}$, respectively, compared with $90 \mathrm{~g}$ for the control diet. Cactus, therefore, can be used as a food supplement and water resource.

Keywords: forage cactus, Nopalea cochenillifera, weight gain

\section{RESUMO}

A falta de água na produção pecuária pode ser um fator limitante para o bom desempenho dos animais. $\mathrm{O}$ objetivo deste trabalho foi avaliar $\mathrm{o}$ efeito da restrição total de água na dieta de ovinos, alimentados com palma forrageira sobre 0 desempenho produtivo. Foram utilizados 42 ovinos, machos, com idade e peso médio de \pm 100 dias e $18,75 \pm \quad(2,05) \mathrm{kg}$, respectivamente; alimentados com dietas de 0, 3050 e $70 \%$ de inclusão de palma forrageira. Os animais foram abatidos quando atingiam o peso de $32 \mathrm{~kg}$ ( $\pm 1 \mathrm{~kg}$ ) ou 90 dias em confinamento. $\mathrm{O}$ desenho experimental foi arranjo fatorial $3 \times 2$, inclusão de palma (30, 50 70\%) x água (com água ou sem água). As variáveis foram analisadas utilizando o teste Tukey a 5\% de probabilidade, pelo programa PROC GLM do SAS. Os consumos voluntários de água e de matéria seca diminuíram $(P<0,05)$ com a inclusão de palma forrageira nas dietas, porém o consumo de água através dos alimentos e consumo total água aumentaram com a inclusão de palma forrageira $(P<0,05)$. A restrição de água e a interação com os níveis de palma não teve influencia no desempenho dos animais $(\mathrm{P}>0,05)$. $\mathrm{O}$ ganho de peso diário foi maior para os tratamentos com 30 e $50 \%$ de inclusão de palma, com ganhos de 174 e $155 \mathrm{~g}$, respectivamente, comparado com a dieta controle que obteve ganho médio de $90 \mathrm{~g}$. A palma forrageira pode ser utilizada eficientemente como suplemento alimentar e fonte única de água na dieta.

Palavras chave: ganho de peso, Nopalea cochenillifera, palma forrageira 


\section{INTRODUCTION}

The shortage of water has generated concern in all sectors, and better utilization of this vital liquid is needed. The relationship between water intake and food intake under semi-arid conditions may be a major factor in the low performance of animals because, in the absence of water points, the animals must spend more time and energy seeking other sources of water (BEN SALEM \& SMITH, 2008). Animals can obtain water in three different ways: they primarily obtain water by drinking free water, but they can also obtain preformed water from food (mostly moist foods and succulent foods) (Araújo et al., 2010) or from metabolic water, which is formed during the oxidation of dietary nutrients and catabolism of body tissue (CSIRO, 2007). Diet composition is a determining factor in water intake because nearly all foods, especially succulent foods, contain water (ARAÚJO et al., 2010).

In northeastern Brazil, the water deficit caused by irregular rainfall has caused large losses of capital in the agricultural sector, including an estimated loss of millions of dollars due to livestock production losses. The chances of successful livestock production in semiarid conditions increase with the use of fodder adapted to these environments, such as cactus (CÂNDIDO et al., 2013). Cacti, which are well adapted to semiarid conditions, have a different metabolism, and they are eleven times more water-efficient than other plants. (GALVÃO JÚNIOR et al., 2014).

Cactus has been considered a "bank of life" because it is a good source of water for humans and animals in areas with water scarcity (BEN SALEM \& SMITH, 2010). Forage cactus contains high levels of water (80-90\%), organic matter $(93 \%)$ and carbohydrates $(86.57 \%)$ but low levels of dry matter $(13.6 \%)$ and crude protein $(3.34 \%)$ (VALADARES FILHO et al., 2006). Therefore, forage cactus should be provided along with other foods because in addition to providing insufficient dry matter and nutrients, feeding with forage cactus alone leads to digestive problems (GALVÃO JÚNIOR et al., 2014).

Several animal feed studies have evaluated the effect of water intake by studying cactus. Gebremariam et al. (2006), Bispo et al. (2007) and Tegegne et al. (2007) observed a decrease in the consumption of water from the water trough that correlated with an increase in the consumption of spineless cactus. Therefore, the aim of the present study was to evaluate the effect of total water restriction on the growth performance of sheep that are fed forage cactus.

\section{MATERIALS AND METHODS}

The experiment was conducted at the Centro de Ciências Agrárias, Universidade Federal de Alagoas, Brazil $\left(9^{\circ} 27^{\prime} \mathrm{S}, 35^{\circ} 27^{\prime} \mathrm{W}\right)$, with an altitude of $127 \mathrm{~m}$, a minimum average temperature of $23.94{ }^{\circ} \mathrm{C}$ and maximum of $33.14^{\circ} \mathrm{C}$, and relative humidity of 25.77. The research project was approved by the Ethics Commission of the Federal University of Alagoas, with the number 56/2016.

Forty-two healthy male Santa Inês sheep a with an average age and weight of \pm 100 days and $18.75 \pm(2,05) \mathrm{kg}$, respectively, were included in the study. - The animals were submitted to an adaptation period of 14 days. The animals were kept in individual pens, with food and water troughs, and were 
distributed in a 3 (forage cactus percentages) $\mathrm{x} 2$ (with or without water) random factorial design plus a control group $(n=6)$. Animals were fed diets that were formulated according to the NRC (2007) for weight gain of 150 g/animal/day, which consisted of three levels of substitution $(30,50$ or $70 \%)$ of Tifton hay with forage cactus (Nopalea cochenillifera), concentrate (corn, soybean and soybean oil) and mineral mixture (Table 1).

Table 1. Ingredients and chemical composition of the experimental diets based on dry matter

\begin{tabular}{|c|c|c|c|c|}
\hline \multirow[b]{2}{*}{ Ingredients } & \multicolumn{4}{|c|}{ Forage cactus levels $(\%)$} \\
\hline & 0 & 30 & 50 & 70 \\
\hline Forage cactus & 0.00 & 30.00 & 50.00 & 69.04 \\
\hline Tifton hay & 70.00 & 40.00 & 20.00 & 4.91 \\
\hline Corn & 18.3 & 13.8 & 10.3 & 4.70 \\
\hline Soybean & 7.00 & 13.00 & 17.50 & 19.70 \\
\hline $\begin{array}{l}\text { Mineral } \\
\text { supplement }\end{array}$ & 1.70 & 1.7 & 1.7 & 1.65 \\
\hline Soybean oil & 3.00 & 1.5 & 0.5 & 0.00 \\
\hline \multicolumn{5}{|c|}{ Chemical composition (\% DM) } \\
\hline $\mathrm{DM}(\%)$ & 88.67 & 34.10 & 24.19 & 18.95 \\
\hline $\mathrm{CP}(\%)$ & 11.45 & 12.43 & 13.28 & 13.23 \\
\hline NDF $(\%)$ & 58.03 & 42.25 & 31.74 & 24.15 \\
\hline $\operatorname{ash}(\%)$ & 7.89 & 9.71 & 10.95 & 12.21 \\
\hline $\mathrm{TC}(\%)$ & 75.60 & 74.32 & 73.26 & 72.63 \\
\hline $\mathrm{NFC}(\%)$ & 17.57 & 32.07 & 41.52 & 48.48 \\
\hline $\mathrm{EE}(\%)$ & 5.06 & 3.54 & 2.51 & 1.93 \\
\hline NDT & 63.72 & 66.35 & 68.08 & 69.00 \\
\hline ME (Mcal/kg) & 2.808 & 2.92 & 3.00 & 3.04 \\
\hline
\end{tabular}

Forage Cactus: DM-14.0; CP-4.0; NDF-24.0; EE-1,86; TC-72.04; NFC-44.04\%. DM: Dry matter; CP: Crude protein; NDF: Neutral detergent fiber; ADF: Acid detergent fiber; TC: Total carbohydrates; NFC: Non fiber carbohydrates; EE: Ether extract; ME: Metabolizable energy.

Diets were mixed manually in the feeder. The food supply was performed twice a day $(50 \%$ in the morning and $50 \%$ in the afternoon), allowing $10 \%$ of leftovers until reaching $32 \mathrm{~kg}( \pm 1 \mathrm{~kg})$ of body weight or 90 days in confinement, and then slaughtered. Five kilograms of water were offered daily, and leftovers were weighed and discarded for a new supply of clean water, with the exception of animals in total water restriction. The animals were fed twice per day and were allowed to retain 10\% of the food as leftovers, until they reached $32 \mathrm{~kg}$ and were slaughtered. Water was offered to all animals except those with water restriction. The sheep were offered $5 \mathrm{~kg}$ of water, and leftovers were weighed and discarded before fresh, clean water was provided; the water intake was recorded daily (24 hours).The evaporative water losses were considered.

Total water intake included the water derived from food, drinking water and metabolic water production. The preformed water was considered as the water contained in the foods, and their intake was calculated as the difference between the in natura food intake and the dry matter intake. The metabolic water production was estimated through the nutrients intake, assuming that $41 ; 55$ and $107 \mathrm{~g}$ of water are produced from 100 
grams of protein, starch and fat consumed, respectively (BOSSINGHAM et al., 2005). Dry matter intake (DMI) was determined by weighing the food that was offered and refused throughout the experiment The composition of feed and leftovers were analyzed according to the methodology by AOAC (1997). Animals were weighed every seven days to evaluate weight gain

Data from treatments with forage cactus (30,50 and 70\%) and water supply (with or without water) were analyzed using the Tukey's test at 5\% The Orthogonal test was used to compare the control treatment $(0 \%)$ with treatments with forage cactus inclusion. The variables were analyzed using the PROC GLM procedure of SAS (Version 9.2: SAS Institute INC., Cary NC).

\section{RESULTS AND DISCUSSION}

Voluntary water intake and DMI decreased $(\mathrm{P}<0.05)$ with the inclusion of forage cactus (Table 2); the lowest intake was recorded for the sheep fed a diet of $70 \%$ forage cactus. Other scientists (VIEIRA et al., 2008; MENDEZ-LLORATE et al., 2011; COSTA et al., 2012) have reported that increasing the proportion of forage cactus in the diet (above 50\%) reduced dry matter intake. Forage cactus has a low dry matter content, which explains the reduction in the DMI; distension of the digestive tract limits the intake of food, even if the nutritional requirements are not met (VAN SOEST, 1994).

The voluntary intake of water decreased $(\mathrm{P}<0.05)$ from $1.80 \mathrm{~kg}$ (control) to $0.207 \mathrm{~kg}(70 \%$ forage cactus), but the intake of water through the food and total water intake (preformed water in the diet, beverage water and water metabolic production) increased with the inclusion of forage cactus $(\mathrm{P}<0.05)$. This behavior may be due to the composition of forage cactus, which is approximately $86.0 \%$ water, and its correspondingly low dry matter content $(14.0 \%)$; thus, all of this water is consumed by animals directly from forage cactus. The metabolic water production estimate was significant $(\mathrm{P}<0.05)$ between treatments. The production of metabolic water is important, mainly for the determination of the water balance (MORRISON, 1953). The total water intake (water offered + water contained in the diet + metabolic water) was significantly greater $(\mathrm{P}<0.05)$ for animals that were provided water ad libitum (Figure 1). The interaction (Treatment $\mathrm{x}$ Water) was significant $(\mathrm{P}<0.05)$. Differences were observed mainly in the $30 \%$ inclusion treatment, being smaller in the animals under water restriction.

When water is provided freely, the animal's total intake is correlated with DMI. The total water intake can be expressed using the equation TWI= 3.86*DMI-0.99 (NRC, 2007), where $1 \mathrm{~kg}$ of DMI results in 2.871 of water intake. Similar results were observed in the control group in this experiment; the animals in the control group consumed $0.84 \mathrm{~kg}$ of DMI and 1.881 of water, which is close to the value obtained from the equation. An animal's feed and water intake depends on several variables related to the animal (metabolic requirements, hormonal stimuli, satiety, etc.), food (nutritional value, particle size, etc.) and water (availability and salinity) (CHURCH, 1988; SILANIKOVE, 1989; VAN SOEST, 1994; NRC, 2007; ARAÚJO et al., 2010). 
Rev. Bras. Saúde Prod. Anim., Salvador, v.18, n.2, p.369-377 abr./jun., 2017

ISSN 15199940

http://mc04.manuscriptcentral.com/rbspa-scielo http://dx.doi.org/10.1590/S1519-99402017000200015

Table 2. Water intake, dry matter intake and average daily gain of Santa Inês sheep fed forage cactus

\begin{tabular}{|c|c|c|c|c|c|c|c|c|c|c|}
\hline \multirow{2}{*}{ Parameters } & \multicolumn{4}{|c|}{ Forage cactus levels $\%$} & \multirow{2}{*}{$\mathrm{P}$} & \multicolumn{2}{|c|}{ Water } & \multirow{2}{*}{$\mathrm{P}$} & \multirow{2}{*}{$\frac{\mathrm{FC}^{*} \mathrm{~W}}{\mathrm{P}}$} & \multirow[b]{2}{*}{ RMSE } \\
\hline & 0 & 30 & 50 & 70 & & with & without & & & \\
\hline DMI (kg) & $0.84 *$ & $0.92^{\mathrm{a}}$ & $0.80^{\mathrm{b}}$ & $0.68^{\mathrm{c}}$ & 0.0001 & 0.81 & 0.80 & 0.81 & 0.15 & 0.160 \\
\hline $\mathrm{ADG}(\mathrm{kg})$ & $0.09 *$ & $0.174^{\mathrm{a}}$ & $0.155^{\mathrm{ab}}$ & $0.111^{\mathrm{b}}$ & 0.010 & 0.148 & 0.146 & 0.879 & 0.674 & 0.031 \\
\hline Voluntary intake of water $(\mathrm{kg} / \mathrm{d})$ & $1.80^{*}$ & $0,48^{\mathrm{a}}$ & $0.32^{\mathrm{ab}}$ & $0.22^{\mathrm{b}}$ & 0.0392 & 0.69 & 0.0 & 0.0001 & 0.03 & 0.252 \\
\hline Preformed water $(\mathrm{kg} / \mathrm{d})$ & $0.073^{*}$ & $2.05^{\mathrm{c}}$ & $2.59^{\mathrm{b}}$ & $2.86^{\mathrm{c}}$ & 0.0001 & 2.47 & 2.52 & 0.6676 & 0.49 & 0.267 \\
\hline Metabolic water $(\mathrm{g} / \mathrm{d})$ & $197.14^{*}$ & $280.75^{\mathrm{a}}$ & $279.83^{\mathrm{a}}$ & $249.06^{\mathrm{b}}$ & 0.0176 & 272.80 & 266.9 & 0.5397 & 0.66 & 22.982 \\
\hline Ratio of Water:DM (L/kg MS) & $2.24^{*}$ & $2.74^{\mathrm{c}}$ & $3.63^{\mathrm{b}}$ & $4.49^{\mathrm{a}}$ & 0.0001 & $4.01^{\mathrm{a}}$ & $3.23^{\mathrm{b}}$ & 0.0008 & 0.87 & 0.458 \\
\hline Total water intake $(\mathrm{kg})$ & $2.07 *$ & 2.82 & 3.19 & 3.29 & 0.0446 & $3.41^{\mathrm{a}}$ & $2.79^{\mathrm{b}}$ & 0.0006 & 0.023 & 0.373 \\
\hline
\end{tabular}

Total water intake (kg)

$\mathrm{RMSE}=$ root mean square errorr. DMI: Dry matter intake; FC*W: Forage cactus and water interaction.

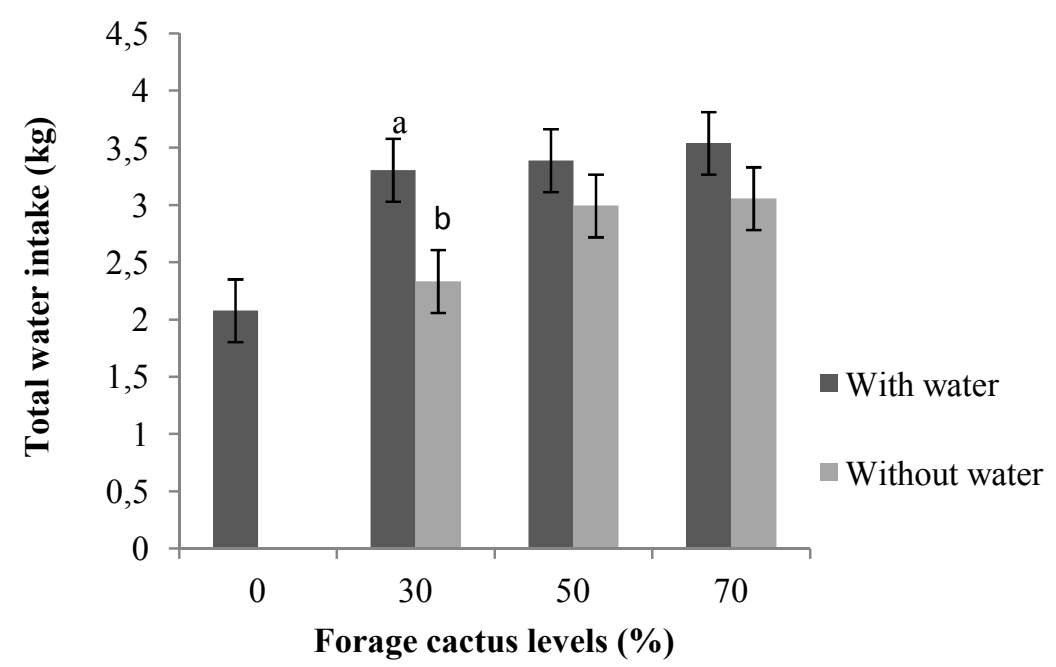

Figure 1. Total water intake (food water + drinking water + metabolic water) of animals fed with forage cactus 
Significant differences $(\mathrm{P}<0.05)$ were observed in relation to total water intake and dry matter intake (1/ kg DM). The ratio of total water intake / DMI $(1 / \mathrm{kg}$ $\mathrm{DM})$ increased $(\mathrm{P}<0.05)$ from $2.24 \mathrm{l} / \mathrm{kg}$ $\mathrm{DM}(0 \%$ forage cactus) to $4.441 / \mathrm{kg} \mathrm{DM}$ (70\% forage cactus). Among the treatments with or without water, it was observed a greater $(\mathrm{P}<0.05)$ water intake in the animals with water ad libitum (Figure 2), mainly in the treatment with 30 and $50 \%$ of inclusion of forage cactus. When forage cactus was used in the diet, the DMI was reduced. According to the NRC (2007), the reduction in dry matter intake (DMI) implies less need for water intake (in relation to DMI); nevertheless, with the addition of forage cactus, the intake of water (L/kg DMI) increased via a reduction in voluntary water intake and an increase in water from food because forage cactus is rich in non-fiber carbohydrates and water.

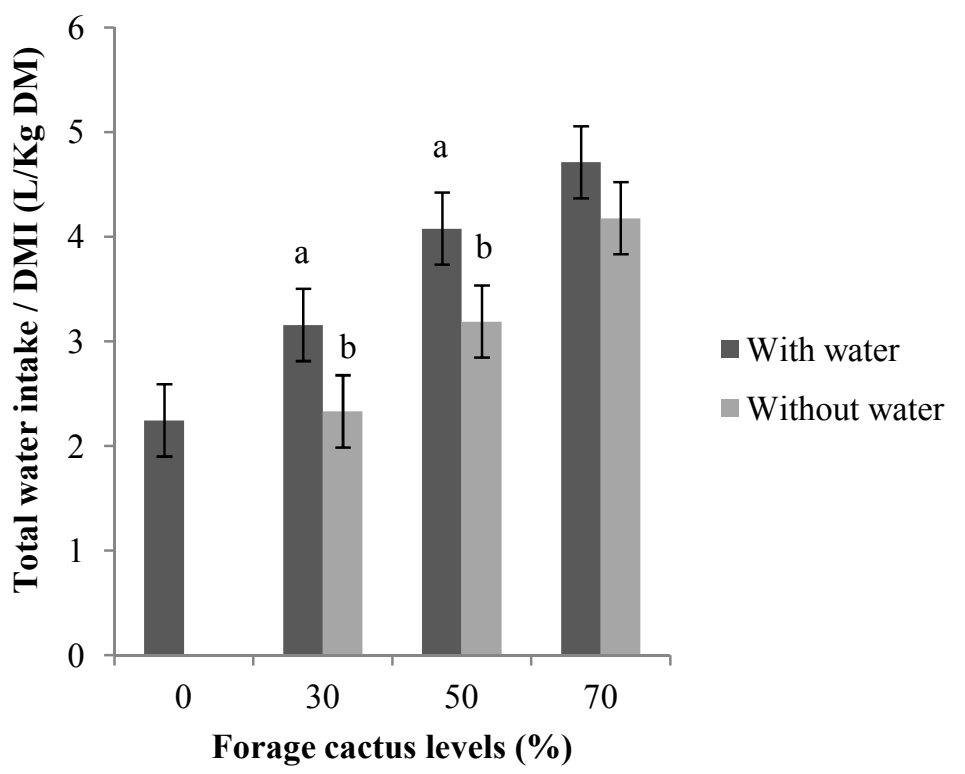

Figure 2. Water intake/ Dry matter intake ratio (1/ kg DM) of animals fed with forage cactus

The water restriction throughout the entire experiment ( 85 days on average) did not have a negative effect on animal performance. Instead, we observed higher weight gains for treatments including 30 and $50 \%$ forage cactus (167 and 153g, respectively) compared to the control diet (106g), strengthening the argument for the value of forage cactus as a water resource.

Some authors have evaluated the effect of water restriction on animal performance (AGANGA et al., 1990;
ALAMER \& Al-HOZAB, 2004) observed that decrease in water consumption reduces the dry matter intake in sheep. This reduction in food consumption results in a decrease in the productive performance of the animal. In this experiment, water restriction throughout the entire experiment did not have a negative effect on animal performance. The results demonstrate that forage cactus is an excellent source of water since the total water intake was higher when using forage cactus 
compared to the control treatment. The higher the level of forage cactus inclusion, the greater total water intake, strengthening the argument for the value of forage cactus as a water resource.

Forage cactus has previously been documented as a food supplement or ingredient substitute (BEN SALEM, 2010; SOUZA et al., 2010). The use of forage cactus improves the performance of animals because it increases the digestibility of other nutrients (BISPO et al., 2007; ANDRADE-MONTEMAYOR et al., 2011). While increases in the weight gain of animals that are fed a diet including 20 to $50 \%$ forage cactus have been observed, decreases in weight gain have been observed when more than $50 \%$ of the diet consists of forage cactus, as observed in this study. It is worth noting that even with $70 \%$ forage cactus content in the diet, the animals showed higher weight gain than those subjected to the control treatment $(121 \mathrm{~g} /$ day vs. $106 \mathrm{~g} /$ day).

Total drinking water restriction in sheep that are fed forage cactus does not affect body weight gain. We recommend the inclusion of 30 to $50 \%$ forage cactus in the diet for sheep production systems because that level of forage cactus inclusion led to the greatest improvements in daily and total weight gain. Therefore, forage cactus can be used as both a food supplement and a source of water.

\section{ACKNOWLEDGMENTS}

The authors wish to thank the CNPq, Brazilian National Council for Scientific and Technological Development - Brazil and TWAS, The Academy of Sciences for the Developing World for their support.

\section{REFERENCES}

AGANGA, A.A.; UMUNNA, N.N.; OYEDIPE, E.O.; OKOH, P.N.; ADUKU, A.O. Response to water deprivation by Yankasa ewes under different physiological states. Small Ruminant Research, v.3, p.109-115, 1990.

ALAMER, M.; AL-HOZAB, A. Effect of water deprivation and season on feed intake, body weight and thermoregulation in Awassi and Najdi sheep breeds in Saudi Arabia. Journal of Arid Environment, v.59, p.71-84, 2004

ANDRADE-MONTEMAYOR, H.M.; CORDOVA-TORRES, A.V.; GARCÍA-GASCA, T.; KAWAS, J.R.. Alternative foods for small ruminants in semiarid zones, the case of Mesquite (Prosopislaevigata spp.) and Nopal (Opuntia spp.). Small Ruminant

Research, v.98, p83-92, 2011.

ASSOCIATION OF OFFICIAL ANALYTICAL CHEMIST - AOAC. Official methods of analysis. 16th ed. Gaithersburg: Association of Official Analytical Chemist, 1997.

ARAÚJO G.G.L.; VOLTOLINI, T.V.; CHIZZOTTI, M.L.; TURCO S.H.N.; CARVALHO F.F.R.. Water and small ruminant production. Revista

Brasileira de Zootecnia, v.39, p.326336, 2010

BEN SALEM, H.; SMITH, T. Feeding strategies to increase small ruminant production in dry environments. Small Ruminant Research, v.77, p.174-194, 2008. 
BEN SALEM, H. Nutritional management to improve sheep and goat performances in semiarid regions.

Revista Brasileira de Zootecnia v.39, p337-347,2010.

BISPO, S.V.; FERREIRA, M.A.; VÉRAS, A.S.C.; BATISTA, A.M.; PESSOA, R.A.; BLEUEL, M.P. Palma forrageira em substituição ao feno de capim-elefante. Efeito sobre consumo, digestibilidade e características de fermentação ruminal em ovinos.

Revista Brasileira de Zootecnia, v.36, p.1902-1909, 2007.

BOSSINGHAM, M.J.; CARNELL, N.S.; CAMPBELL, W. W. Water balance, hydration status, and fat-free mass hydration in younger and older adults. The American Journal of Clinical Nutrition, v. 81, n.6, p.13421350, 2005.

CÂNDIDO, M.J.D.; GOMES, G.M.F.; LOPES, M.N.; XIMENES, L.J.F. Cultivo de palma forrageira para mitiar a escassez de forragem em regiões semiáridas. Banco do Nordeste do brasil. Informe Rural, v.7, n.3, 2013.

CHURCH D.C. The ruminant animal: digestive physiology and nutrition. Englewood Cliffs, NJ, USA: Prentice Hall, 1988.

COSTA, R.G.; HERNANDEZ, T.I.; MEDEIROS, A.N.; AZEVEDO, O.S.; PINTO, T.F.; DELGADO, J.V.

Consumo de água de ovinos alimentados com diferentes de nopal (Opuntia ficus indica) em Brasil. Archivos de Zootecnia, v.61, p.301304, 2012.

COMMONWEALTH SCIENTIFIC AND INDUSTRIAL RESEARCH ORGANIZATION - CSIRO. Nutrient requirements of domesticated ruminants. commonwealth scientific and industrial research organization. Collingwood, Australia: CSIRO Publishing, 2007.

GEBREMARIAM, T.; MELAKU, S.; YAMI, A. Effect of different levels of cactus (Opuntia ficus-indica) inclusion on feed intake, digestibility and body weight gain in tef (Eragrostistef) strawbased feeding of sheep. Animal Feed Science and Technology, v.131, p.4251, 2006.

GALVÃO JÚNIOR, JGB.; SILVA, J.B.A.; MORAIS, J.H.G.; LIMA, R.N. Palma forrageira na alimentação de ruminantes: cultivo e utilização. Acta Veterinaria Brasilica, v.8, p.78-85, 2014

MENDEZ-LLORATE, F.; RAMÍREZLOZANO, R.G.; LOPEZ, M.A., RODRIGUEZ-FRAUSTO, H.; ARECHIGA-FLORES, C.F.; BONILLA-SALAZAR, A.; NUÑEZGONZALEZ, M.; AGUILERA-SOTO, J.I. Performance and nutrient digestion of lambs fed incremental levels of wild cactus (Opuntia leucotrichia).Journal of Applied Animal Research, v.39, p.248-251, 2011.

MORRISON, S.D. A method for the calculation of metabolic water. The Journal of Physiology, v.122, n.2, p.399-402, 1953.

\section{NUTRIENT REQUIREMENTS COMMITTEE. Nutrient}

\section{Requirements of Small Ruminants:}

Sheep, goats, cervids, and New World camelids/Committee on Nutrient Requirements of Small Ruminants. Board on Agriculture and Natural Resources. Division on Earth and Life Studies. NRC. First Edition. Washington, DC, 2007. 
TEGEGNE, F.; KIJORA, C.; PETERS, KJ. Study on the optimal level of cactus pear (Opuntiaficus-indica)

supplementation to sheep and its contribution as source of water. Small

Ruminant Research, v.72, p.157-164, 2007.

SAS INSTITUTE. SAS/STAT: user's

Guide. Version 9.2. Cary, 2009.

SILANIKOVE, N. Interrelationships between water, food, and digestible energy intake in desert and temperate goats. Appetite, v.12, p.163- 170,1989.

SOUZA, C.M.S.; MEDEIROS, A.N.; FURTADO, D.A.; BATISTA, A.M.V.; FILHO, P.E.C.; SILVA, D.S.

Desempenho de ovelhas nativas em confinamento recebendo palmaforrageira na dieta na região do semiarido nordetino. Revista Brasileira de Zootecnia, v.39, p.1146-1153, 2010.

VALADARES FILHO, S.C.; MAGALHÃES, K.A.; ROCHA JÚNIOR, V.R.; CAPELLE, E.R.

Tabelas brasileiras de composição de alimentos para bovinos. Viçosa: Universidade Federal de Viçosa, 2006.

VAN SOEST, P.J., Nutritional ecology of the ruminant. 2.ed. Ithaca: Cornell University Press, 1994.

VIEIRA, E.L.; BATISTA, A.M.V.; GUIM, A.; CARVALHO, F.F.; NASCIMETO, A.C.; ARAÚJO, R.F.S.; MUSTAFA, A.F. Effects of hay inclusion on intake, in vivo nutrient utilization and ruminal fermentation of goats fed spineless cactus (Opuntia ficus - indica Mill) based diets. Animal Feed Science and Technology,v.141, p.199-208, 2008.

Data de recebimento: $14 / 12 / 2016$

Data de aprovação: 17/05/2017 